УДК 336.63:330.322

DOI: https://doi.org/10.37320/2415-3583/13.20

Марина A.C.

кандидат економічних наук, доцент, ДВНЗ «Донеиький начіональний технічний університет» ORCID: https://orcid.org/0000-0001-5634-9402

Волкова Ю.В. аспірант кафедри управління і фінансово-економічної безпеки, ДВНЗ «Донецьький національний технічний університет»

\title{
ФІНАНСИ ДОМОГОСПОДАРСТВ В СТРУКТУРІ ІНВЕСТИЦІЙНИХ РЕСУРСІВ КРАЇНИ
}

Фінанси домогосподарств є значним джерелом фінансових ресурсів з огляду на можливість їх залучення до інвестування реального сектору економіки, зокрема промислового виробниитва. Структура економіки країни свідчить про переважну роль промисловості у створенні внутрішнього валового продукту, водночас промислові підприємства відчувають суттєвий брак фінансових ресурсів для забезпечення стабільного та стійкого розвитку своєї господарської діяльності, безпеки фінансового стану. Це спонукає промислові підприємства до пошуку альтернативних джерел фінансування. Заощадження, які є частиною фінансів домогосподарств $i$ не знаходять застосування на фінансовому ринку як кредитний капітал, иілком можна використовувати як інвестиційні ресурси промислових підприємств. У статті проведено дослідження структури та джерел формування доходів домогосподарств, а також основних напрямів витрачання коштів домогосподарствами України.

Ключові слова: фінанси домогосподарств, витрати домогосподарств, інвестиції, структура доходів $i$ витрат домогосподарств, заощадження, інвестиційні ресурси.

Постановка проблеми. Інвестиційні ресурси, безумовно, відіграють найважливішу роль у забезпеченні сталого розвитку вітчизняних підприємств. Притаманна інвестиціям спроможність до активізації виробничих процесів та формування підгрунтя сталого розвитку обумовлює інтерес до них як з боку науковців, так і з боку 
практиків. Причому під час дослідження джерел походження інвестиційних ресурсів найбільша увага приділяється інституціональним інвесторам, механізмам та інструментам розміщення наявних у них тимчасово вільних фінансових ресурсів. Така розстановка акцентів обумовлена зосередженням більшої частки інвестиційних ресурсів саме в руках інституційних інвесторів. Водночас певна частка активів є виключеною 3 фінансового обігу у формі заощаджень домогосподарств, які можуть слугувати альтернативним джерелом інвестиційних ресурсів для економіки країни.

Аналіз останніх досліджень і публікацій. Вивчення фінансів домогосподарств зводиться найчастіше до аналізу структури та динаміки доходів та витрат населення, прогнозування їх структури та динаміки [1-4]. Певні дослідження присвячені ролі фінансів домогосподарств у структурі національної фінансової системи [4; 5], структурі інвестиційних ресурсів окремих сфер фінансової системи [3]. Проте оцінювання місця фінансів домогосподарств у структурі джерел інвестиційних ресурсів країни потребує подальшого дослідження 3 урахуванням можливості залучення заощаджень населення до фінансування розвитку окремих галузей економіки країни.

Мета статті полягає у дослідженні перспектив залучення фінансів домогосподарств до формування інвестиційних ресурсів промислових підприємств на основі дослідження динаміки формування заощаджень домогосподарств та обсягів інвестицій промислових підприємств.

Виклад основного матеріалу. Фінанси домогосподарств є одним 3 ключових елементів національної фінансової системи, адже пов'язують різні сектори національної економіки в процесі формування, розподілу та використання фінансових ресурсів. Крім того, домогосподарства $є$ джерелом фінансових активів для фінансового ринку країни під час розміщення власних заощаджень у формі депозитів, придбання цінних паперів, активів підприємств тощо. За умов нестачі власних фінансових ресурсів вони вступають у кредитні відносини з основними фінансовими посередниками, а саме банками, кредитними спілками, ломбардами.
3 огляду на наявність низки трактувань поняття «фінанси домогосподарств» (табл. 1) до цієї категорії відносять як потоки коштів, сукупність економічних відносин, так і самостійну сферу фінансових відносин.

В зарубіжній науковій літературі більш уживаним $\epsilon$ термін «особисті фінанси», який охоплює дослідження особистих ("personal") та сімейних фінансових ресурсів. Під час дослідження особистих фінансів вивчаються напрями використання, заощадження та інвестицій наявних фінансових ресурсів; фінансове планування, складання бюджету, податкове управління, управління готівкою та використання кредитних карт, запозичення та видатки, управління ризиками, інвестиційне, пенсійне та майнове планування.

Отже, фінанси домогосподарств $є$ міцним підгрунтям для інвестування в економіку країни власних накопичених коштів. Нині вивчення питання фінансів домогосподарств є досить цікавим, оскільки їх роль в економічній системі країни поступово підвищується. Актуальними питаннями сьогодення $€$ необхідність ефективного використання доходів і витрат домогосподарств під час формування фінансових ресурсів держави, доцільність їх реалізації в інвестиційних процесах.

Фінанси домогосподарств набувають статусу інвестиційних ресурсів у разі прийняття рішення щодо вкладення власних заощаджень в об' єкти будь-якої діяльності, зокрема підприємницької, задля збільшення їх вартості. Згідно 3 даними Державної служби статистики України [10], кількість домогосподарств $€$ майже незмінною протягом останніх трьох років: у 2017 р. вона становить 14 985,6 тис., у 2018 р. - 14 934,9 тис., у 2019 р. - 14881,7 тис. Зменшення загальної кількості домогосподарством викликано складною демографічною ситуацією, зокрема, $є$ результатом еміграційних процесів. Останніми роками відбувається відтік економічно активного населення із сільської місцевості до великих міст, а з великих міст до інших країн, що негативно відбивається на чисельності вітчизняних домогосподарств, спроможних до акумулювання заощаджень, які можуть бути використані як додаткові ресурси на фінансовому ринку. Досить вагомим фактором у процесі активізації еміграційних процесів є анексія Криму та бойові дії на Сході України.

Таблиця 1 - Підходи до трактування категорії «фінанси домогосподарств»

\begin{tabular}{|c|c|c|}
\hline № & Автор & Визначення \\
\hline 1 & $\begin{array}{l}\text { С. Лондар, } \\
\text { О. Тимошенко } \\
\quad[7]\end{array}$ & $\begin{array}{l}\text { Фінанси домогосподарств - це регульовані у визначеному правовому полі за допомогою } \\
\text { спеціальних методів, прийомів та інструментарію потоки коштів через мікрорівневу систему } \\
\text { грошових фондів, які забезпечують функціонування й розвиток людей як фізичних осіб, їх } \\
\text { економічну діяльність задля придбання житла, підтримання здоров’я, здобуття освіти, отримання } \\
\text { пенсії, забезпечення інших аспектів людської діяльності. }\end{array}$ \\
\hline 2 & $\begin{array}{l}\text { С. Юрій, } \\
\text { Т. Кізіма [3] }\end{array}$ & $\begin{array}{l}\text { Фінанси домогосподарств - це сукупність економічних відносин, матеріалізованих у грошових } \\
\text { потоках, у які вступають домашні господарства щодо формування, розподілу й використання } \\
\text { коштів фондів задля задоволення матеріальних і духовних потреб своїх членів. }\end{array}$ \\
\hline 3 & $\begin{array}{c}\text { О. Рудницька } \\
{[4]}\end{array}$ & \begin{tabular}{|l} 
Фінанси домогосподарств об’єктивно є самостійною сферою фінансових відносин, тому її \\
необхідно обов’язково відокремлювати під час структуризації фінансової системи держави.
\end{tabular} \\
\hline 4 & \begin{tabular}{|c|} 
A. Ланза \\
$\left(\begin{array}{c}\text { Lanza, Anthony G.) } \\
{[8]}\end{array}\right.$ \\
\end{tabular} & $\begin{array}{l}\text { Особисті фінанси складаються з різних частин, але їх можна узагальнити як складання бюджету, } \\
\text { встановлення пріоритетів витрат і заощаджень, планування грошових потоків та ефективну } \\
\text { максимізацію вигід за допомогою програм винагород. }\end{array}$ \\
\hline 5 & $\begin{array}{l}\text { В. Кентон } \\
\text { (Kenton, W) [9] }\end{array}$ & $\begin{array}{l}\text { Особисті фінанси - це термін, який охоплює управління вашими грошима, а також заощадження } \\
\text { та інвестування. Він охоплює бюджетування, банківську діяльність, страхування, іпотеку, } \\
\text { інвестиції, пенсійне планування, а також податкове та майнове планування. Він часто стосується } \\
\text { всієї галузі, яка надає фінансові послуги фізичним особам та домогосподарствам, а також } \\
\text { консультує їх щодо фінансових та інвестиційних можливостей. }\end{array}$ \\
\hline
\end{tabular}


Згідно $з$ даними Державної служби статистики України, у структурі сукупних ресурсів домогосподарств переважають грошові доходи у формі заробітної плати (табл. 2). Зростання цього показника опосередковано обумовлено зростанням рівня мінімальної заробітної плати

Щодо динаміки, яка спостерігається у структурі сукупних ресурсів домогосподарств, можна виділити збільшення частки грошових доходів. Це насамперед пов'язано з підвищенням рівня оплати праці та активною участю населення у розвитку підприємницької діяльності. Стосовно інших показників, то вони зменшуються, що пов'язано з нестабільною політичною та економічною ситуацією в Україні, продовженням військового конфлікту на території крани.

Згідно з даними Державної служби статистики, витрати домогосподарств України у 2016-2019 рр. мали майже постійну структуру (табл. 3).

Більшу частину видатків вітчизняних домогосподарств складають витрати на забезпечення першочергових потреб, зокрема витрати на продукти харчування, житлово-комунальні послуги, охорону здоров'я й тран- спортні послуги. Водночас спостерігається зменшення видатків на споживчі сукупні витрати за умови збільшення відсотку витрат на неспоживчі сукупні витрати.

Відповідно до глосарію термінів Державної служби статистики в Україні, «неспоживчі сукупні витрати складаються з грошових та негрошових витрат домогосподарства на допомогу родичам та іншим особам, витрат на купівлю нерухомості, на капітальний ремонт, будівництво житла та господарських будівель, на купівлю великої рогатої худоби, коней та багаторічних насаджень для особистого підсобного господарства, на придбання акцій, сертифікатів, валюти, вкладів до банківських установ, аліментів, податків (крім прибуткового), зборів, внесків та інших грошових платежів, використаних заощаджень, позик та повернених домогосподарством боргів» [13]. Таким чином, акумулювання заощаджень домогосподарствами також належить до цієї статті видатків.

Заощадження $\epsilon$ одним 3 факторів формування фінансової стійкості та безпеки домогосподарств, проте можуть виступати джерелом додаткових доходів в разі перетворення їх на інвестиційні ресурси. Сьо-

Таблиця 2 - Структура сукупних ресурсів домогосподарств, \%

\begin{tabular}{|l|c|c|c|c|}
\hline \multicolumn{1}{|c|}{ Показник } & $\mathbf{2 0 1 6} \mathbf{~ p .}$ & $\mathbf{2 0 1 7} \mathbf{~ p .}$ & $\mathbf{2 0 1 8} \mathbf{~ p . ~}$ & $\mathbf{2 0 1 9}$ p. \\
\hline Грошові доходи & 86,0 & 875 & 89,9 & 91,4 \\
\hline зокрема, оплата праці & 46,7 & 52,4 & 54,5 & 56,7 \\
\hline доходи від підприємницької діяльності та самозайнятості & 5,2 & 4,4 & 6,0 & 6,4 \\
\hline доходи від реалізації сільськогосподарської продукції & 2,9 & 3,0 & 2,5 & 2,5 \\
\hline пенсії, стипендії, соціальна допомога, надані готівкою & 23,1 & 20,2 & 19,9 & 19,3 \\
\hline грошова допомого від родичів, інших осіб та інші грошові доходи & 8,1 & 7,5 & 7,0 & 6,5 \\
\hline $\begin{array}{l}\text { Вартість спожитої продукції, отриманої з особистого підсобного } \\
\text { господарства та від самозаготівель }\end{array}$ & 4,8 & 4,0 & 3,8 & 3,6 \\
\hline $\begin{array}{l}\text { Пільги та субсидії безготівкові на оплату житлово-комунальних } \\
\text { послуг, електроенергії, палива }\end{array}$ & 4,7 & 4,7 & 2,8 & 9,8 \\
\hline $\begin{array}{l}\text { Пільги безготівкові на оплату товарів та послуг з охорони } \\
\text { здоров’я, туристичних послуг, путівок на бази відпочинку тощо, } \\
\text { на оплату послуг транспорту, зв’язку }\end{array}$ & 0,4 & 0,4 & 0,4 & 0,6 \\
\hline Інші надходження & 4,1 & 3,4 & 3,1 & 2,4 \\
\hline
\end{tabular}

Джерело: сформовано авторами на основі джерел [10; 11$]$

Таблиця 3 - Структура сукупних витрат домогосподарств, \%

\begin{tabular}{|c|c|c|c|c|}
\hline Показник & 2016 p. & 2017 p. & 2018 p. & 2019 p. \\
\hline Споживчі сукупні витрати & 93,2 & 92,9 & 92,0 & 91,2 \\
\hline зокрема, продукти харчування та безалкогольні напої & 49,8 & 47,9 & 47,7 & 46,4 \\
\hline алкогольні напої, тютюнові вироби & 2,9 & 3,1 & 3,4 & 3,1 \\
\hline непродовольчі товари та послуги & 40,5 & 41,9 & 40,9 & 41,7 \\
\hline в тому числі, одяг і взуття & 5,6 & 5,5 & 5,4 & 5,2 \\
\hline житло, вода, електроенергія, газ та інші види палива & 16,0 & 17,0 & 15,2 & 14,7 \\
\hline $\begin{array}{l}\text { предмети домашнього вжитку, побутова техніка та поточне } \\
\text { утримання житла }\end{array}$ & 1,7 & 2,0 & 2,1 & 1,8 \\
\hline охорона здоров'я & 4,2 & 3,8 & 4,0 & 4,2 \\
\hline транспорт & 3,6 & 3,7 & 3,7 & 4,9 \\
\hline зв'язок & 2,3 & 2,4 & 2,6 & 2,8 \\
\hline відпочинок і культура & 1,4 & 1,6 & 1,8 & 1,6 \\
\hline Освіта & 1,0 & 1,1 & 1,0 & 1,1 \\
\hline ресторани та готелі & 2,2 & 2,3 & 2,4 & 2,8 \\
\hline різні товари і послуги & 2,5 & 2,5 & 2,7 & 2,6 \\
\hline Неспоживчі сукупні витрати & 6,8 & 7,1 & 8,0 & 8,8 \\
\hline
\end{tabular}

Джерело: сформовано авторами на основі джерел [10; 12] 
Таблиця 4 - Обсяги заощаджень домогосподарств

\begin{tabular}{|c|c|c|c|c|}
\hline Показник & 2016 p. & 2017 p. & 2018 p. & 2019 p. \\
\hline $\begin{array}{l}\text { Сукупні ресурси в середньому за місяць у розрахунку } \\
\text { на одне домогосподарство, грн. }\end{array}$ & 6238,8 & 8165,2 & 9904,1 & 11930,4 \\
\hline $\begin{array}{l}\text { Сукупні витрати в середньому за місяць у розрахунку } \\
\text { на одне домогосподарство, грн. }\end{array}$ & 5720,4 & 7139,4 & 8308,6 & 9628,1 \\
\hline $\begin{array}{l}\text { Сукупні заощадження в середньому за місяць у } \\
\text { розрахунку на одне домогосподарство, грн. }\end{array}$ & 518,4 & 1025,8 & 1595,5 & 2302,3 \\
\hline Кількість домогосподарств, тис. од. & 15033,4 & 14985,6 & 14934,9 & 14881,7 \\
\hline Заощадження домогосподарств, млн. грн. & 7793,31 & 15372,23 & 23828,63 & 34262,14 \\
\hline
\end{tabular}

Джерело: сформовано та обчислено авторами на основі даних джерела [13]

годні з огляду на обсяги заощаджень домогосподарства $є$ досить привабливим джерелом інвестицій для економіки країни (табл. 4).

Динаміка заощаджень домогосподарств України має здебільшого позитивну тенденцію, істотне скорочення спостерігалось у 2016 р., коли приріст заощаджень становив лише 12,59 млрд. грн. Найбільш негативною тенденцією є від'ємний приріст заощаджень у 2019 р. у сумі 116,2 млрд. грн. (рис. 1).

Тимчасово вільні кошти домогосподарств можуть бути представлені організованими та неорганізованими заощадженнями. Організовані заощадження населення мобілізуються та розміщуються банківською системою або небанківськими фінансово-кредитними установами. В Україні поки найдоступнішою формою організованих заощаджень населення $є$ банківські депозити, проте поступово отримують розвиток недержавні пенсійні фонди, страхові заощадження, трастові та інвестиційні фонди.

Неорганізовані заощадження формуються домогосподарствами та найчастіше зберігаються у населення в готівковій формі (в національній та іноземній валютах), коштовностях, дорогоцінних металах, дорогих товарах тривалого користування тощо. Для домогосподарств України зберігання заощаджень у готівковій формі, причому в іноземній валюті, є найкращою формою інвестицій з огляду на нестабільне економічне становище в країні. Така форма заощаджень зменшує сукупний попит i, відповідно, негативно відбивається на сукупній пропозиції.

На жаль, в Україні інвестиційний потенціал населення не задіяний повною мірою. Домогосподарства активно використовують неорганізовані валютні заощадження для фінансування своїх потреб, а могли би спрямовувати їх на розвиток окремих сфер економічної системи. Топ-5 найбільш привабливих галузей економіки України, в які протягом останніх років спрямовується основна частина капітальних інвестицій, наведено на рис. 2.

В Україні найбільш поширеним та найменш ризикованим інструментом зберігання й примноження заощаджень $є$ валютні цінності на депозитних рахунках банків.

Ще одним досить поширеним інструментом перетворення заощаджень на інвестиційні ресурси є виділення коштів на будівництво житла (табл. 5).

Згідно 3 даними Державної служби статистики України, незважаючи на скорочення частки фінансів домогосподарств у фінансування будівництва, обсяги коштів у цій сфері продовжують зростати. Найбільш активно домогосподарства вкладали кошти у будівництво житла $(8,3 \%$ у структурі інвестицій житлового будівництва).

На думку експертів [15], інвестування в нерухомість, зокрема будівництво житлових об'єктів та офісних приміщень, досі залишається найбільш привабливою сферою для тимчасово вільних коштів домогосподарств (рис. 3). Ця сфера характеризується відносно невисокою ризикованістю, тому що в разі економічного зростання в країні ціни на житлові об'єкти поступово зростають, а нерухомість завжди можна продати чи здати в оренду. Відносно безпечним напрямом інвестицій для домогосподарств є фондові організації. Проте в них варто інвестувати не більше 10\% капіталу та використовувати для диверсифікації капіталу й ризиків. Для тривалих капіталовкладень пропонується використовувати дорогоцінні метали. Золото 3

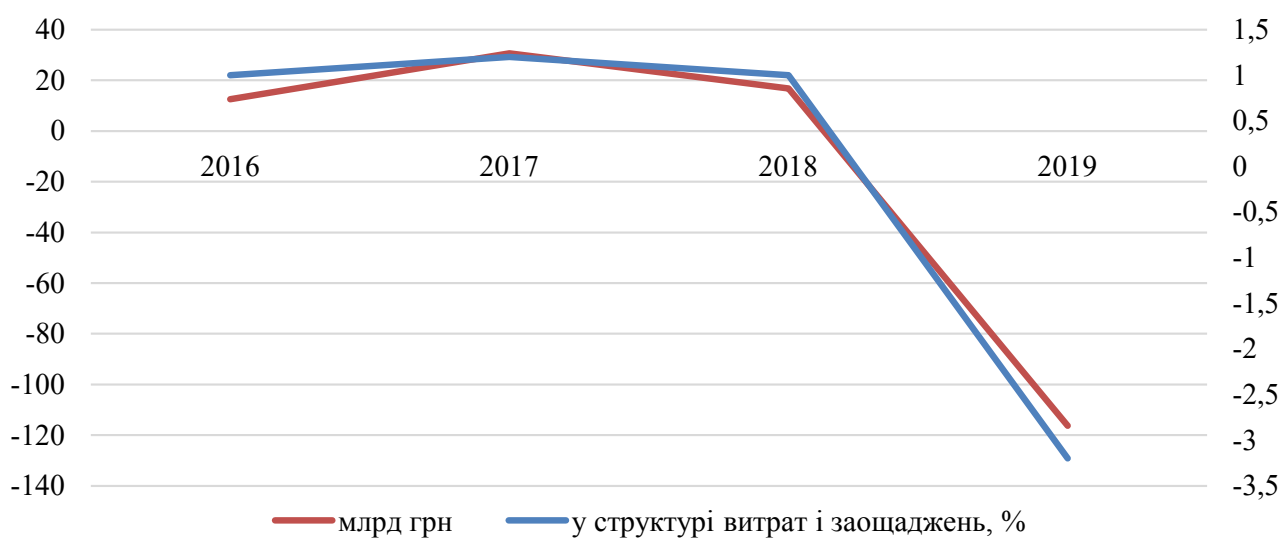

Рисунок 1 - Приріст заощаджень домогосподарств у 2016-2019 рр. 


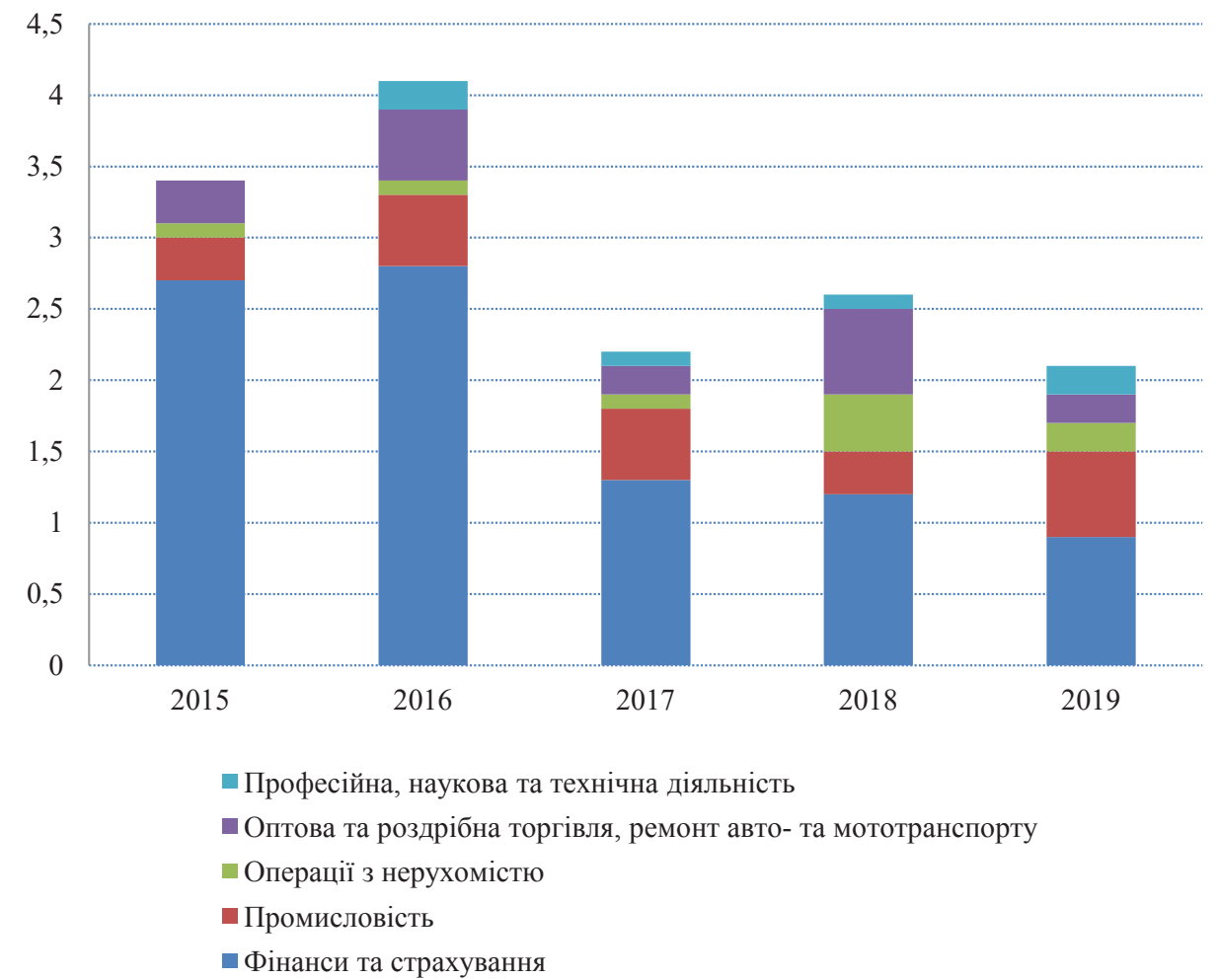

Рисунок 2 - Топ-5 найбільших за обсягами капітальних інвестицій галузей економіки України, млрд. дол. США

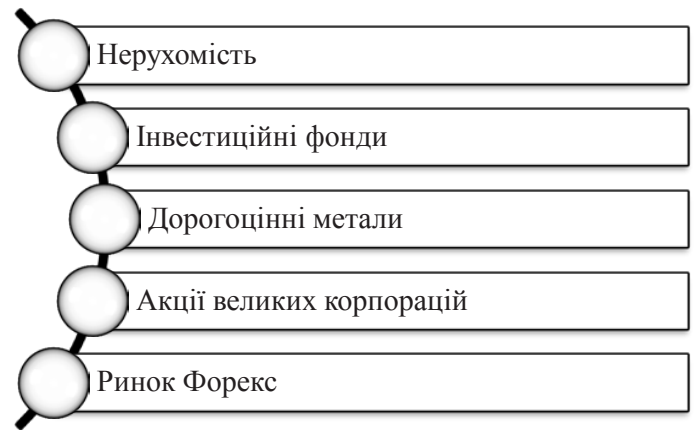

Рисунок 3 - Найбільш привабливі для інвестування в Україні напрями

часом збільшує свою цінність, тому у довгостроковій перспективі ризик отримання збитків від таких фінансових вкладень $є$ мінімальним.

Досить прибутковим, проте й досить ризикованим інвестиційним інструментом $є$ акції великих корпорацій. Домогосподарствам доречно вкладати частину заощаджень у фірми, що мають великий потенціал до зрос- тання. Найбільш прибутковими є стартапи, зокрема впровадження інформаційних та комп'ютерних технологій у різних галузях економіки. Основною від'ємною рисою такого інвестування є складність оцінювання прибутковості того чи іншого проєкту на його старті. Найменш привабливими 3 точки зору інвестування заощаджень домогосподарств $є$ торги на міжнародному майданчику “Forex”. Перевагами такої форми інвестування є високий рівень прибутку й доступність, а основними недоліками високі ризики та необхідність тривалого навчання.

Висновки. Фінанси домогосподарств $є$ вагомою часткою фінансових ресурсів країни, беручи участь у численних фінансових потоках країни. Сьогодні більшість досліджень фінансових ресурсів домогосподарств зводиться до оцінювання та прогнозування їх рівня та динаміки, структури тощо. Проте фінанси домогосподарств можна використовувати як внутрішнє джерело інвестиційних ресурсів для вітчизняних підприємств як через банківську систему, так і через залучення безпосередньо коштів у населення за допомогою фінансових інструментів. За оцінками експертів, сьогодні найбільш привабливими для населення формами

Таблиця 5 - Капітальні інвестиції домогосподарств у житлове будівництво у 2016-2019 рр.

\begin{tabular}{|c|c|c|c|}
\hline Рік & $\begin{array}{c}\text { Кошти населення на } \\
\text { будівництво житла, млн. грн. }\end{array}$ & $\begin{array}{c}\text { Загальна кількість капітальних } \\
\text { інвестицій, млн. грн. }\end{array}$ & $\begin{array}{c}\text { Частка у загальному обсягу } \\
\text { капітальних інвестицій, \% }\end{array}$ \\
\hline 2016 & 29932,6 & 359216,1 & 8,3 \\
\hline 2017 & 32802,5 & 448461,5 & 7,3 \\
\hline 2018 & 34645,7 & 578726,4 & 5,9 \\
\hline 2019 & 32666,4 & 584448,6 & 5,6 \\
\hline
\end{tabular}

Джерело: сформовано авторами на основі джерела [14] 
інвестування $\epsilon$ нерухомість, фінансові компанії, придбання дорогоцінних металів та акцій великих корпорацій. Водночас подальшого дослідження потребують форми, методи та механізми активізації інвестиційної діяльності вітчизняних домогосподарств в умовах економічної та політичної невизначеності.

\section{Список використаних джерел:}

1. Гуржий Т. Динаміка джерел і структури фінансових ресурсів домогосподарств. Інтелект XXI. 2018. № 4. С. 58-63.

2. Мінц О., Джамбаз Н. Механізми формування та використання фінансів домогосподарств в Україні. Theoretical and Practical Aspects of Economics and Intellectual Property. 2017. № 15. C. 226-231.

3. Юрій С., Кізима Т. Фінанси домогосподарств: теоретичні підходи до трактування сутності. Фінанси Украӥни. 2008. № 8. C. 3-10. URL: http://nbuv.gov.ua/UJRN/Fu_2008_8_2 (дата звернення: 11.07.2020).

4. Рудницька О. Економічна природа та роль фінансів домогосподарств у фінансовій системі країни. Економічний вісник університету. 2013. № 20/1. С. 173-178.

5. Нагайчук В. Заощадження домогосподарств як джерело інвестицій в національну економіку. Економіка. Управління. Інноваціï. 2014. № 2(12). URL: http://dspace.tneu.edu.ua/bitstream/316497/6148/1/eui_2014_2_44(1).pdf (дата звернення: 17.07.2020).

6. Кулина Г. Роль фінансів домогосподарству розвитку страхування в Україні. Економіка і суспільство. 2016. № 3. С. 406-411.

7. Лондар С., Тимошенко О. Фінанси : навчальний посібник для студентів вищих навчальних закладів. Вінниця, 2009. 384 с.

8. National Financial Educators Counsil. URL: https://www.financialeducatorscouncil.org/personal-finance-definition (дата звернення: 18.07.2020).

9. Personal Finance. URL: https://www.investopedia.com/terms/p/personalfinance.asp (дата звернення 18.07.2020).

10. Соціально-демографічні характеристики домогосподарств України у 2017 році : статистичний збірник. URL: https://ukrstat.org/uk/druk/publicat/Arhiv_u/17/Arch_cdhd_zb.htm (дата звернення: 20.07.2020).

11. Таблиця структура сукупних ресурсів домогосподарств. URL: http://ukrstat.gov.ua/operativ/operativ2007/gdvdg_rik/ dvdg_u/str_res2010_u.htm (дата звернення: 20.07.2020).

12. Таб̆лиця структура сукупних витрат домогосподарств. URL: http://ukrstat.gov.ua/operativ/operativ2007/gdvdg_rik/ dvdg u/str_vut2010_u.htm (дата звернення: 20.07.2020).

13. Державна служба статистики України. URL: http://www.ukrstat.gov.ua (дата звернення: 17.07.2020).

14. Капітальні інвестиції за джерелами фінансування 2019 року. URL: http:/www.ukrstat.gov.ua/operativ/operativ2019/ibd/ kindj/infin2019 u.htm (дата звернення: 20.07.2020).

15. Куди інвестувати в Україні у 2020 році? URL: https://new.minfin.com.ua/ua/kuda-investirovat-2020 (дата звернення: 20.07.2020).

\section{References:}

1. Gurzhiy, T. (2014). Dynamika dzherel i struktury finansovykh resursiv domohospodarstv [Dynamics of sources and structure of financial resources of households]. Intelekt XXI, no. 4, pp. 58-68.

2. Mints, O., Dzhambaz, N. (2017). Mekhanizmy formuvannia ta vykorystannia finansiv domohospodarstv v Ukraini. [Mechanisms of formation and use of household finances in Ukraine]. Theoretical and Practical Aspects of Economics and Intellectual Property, no. 15, pp. 226-231

3. Yurii, S., Kizyma, T. (2008). Finansy domohospodarstv: teoretychni pidkhody do traktuvannia sutnosti [Household finance: theoretical approaches to the interpretation of the essence]. Finansy Ukrainy, no. 8, pp. 3-10. Available at: http://nbuv.gov.ua/UJRN/ Fu_2008_8_2 (accessed 25 July 2020).

4. Rudnytska, O. (2013). Ekonomichna pryroda ta rol finansiv domohospodarstv u finansovii systemi krainy [Economic essence and the role of household finances in the financial system of the country]. Ekonomichnyi visnyk universytetu, no. 20/1, pp. 173-178.

5. Nahaichuk, V. (2014). Zaoshchadzhennia domohospodarstv yak dzherelo investytsii v natsionalnu ekonomiku [Household savings as a source of investment in the national economy]. Ekonomika. Upravlinnia. Innovatsii, no. 2(12). Available at: /http://dspace.tneu.edu.ua/bitstream/316497/6148/1/eui 20142 44(1).pdf (accessed 17 July 2020).

6. Kulyna, H. (2016). Rol finansiv domohospodarstvu rozvytku strakhuvannia v Ukraini [The role of household finance in insurance development in Ukraine]. Ekonomika i suspilstvo, no. 3, pp. 406-411.

7. Londar, S., Tymoshenko, O. (2009). Finansy [Finance]. Vinnytsia. (in Ukrainian)

8. National Financial Educators Counsil. Available at: https://www.financialeducatorscouncil.org/personal-finance-definition (accessed 18 July 2020).

9. Personal Finance. Available at: https://www.investopedia.com/terms/p/personalfinance.asp (accessed 18 July 2020).

10. Socio-demographic characteristics of Ukrainian households in 2017. Statistical collection. Available at: https://ukrstat.org/uk/ druk/publicat/Arhiv u/17/Arch cdhd zb.htm (accessed 20 July 2020).

11. State Statistic Service of Ukraine. Table structure of total household resources. Available at: http://ukrstat.gov.ua/operativ/ operativ2007/gdvdg_rik/dvdg_u/str_res2010 u.htm (accessed 20 July 2020).

12. State Statistic Service of Ukraine. Table structure of total household expenditures. Available at: http://ukrstat.gov.ua/operativ/ operativ2007/gdvdg rik/dvdg_u/str_vut2010 u.htm (accessed 20 July 2020).

13. State Statistic Service of Ukraine. Available at: http://www.ukrstat.gov.ua (accessed 17 July 2020).

14. State Statistic Service of Ukraine. Capital investments by sources of financing in 2019. Available at: http://www.ukrstat.gov.ua/ operativ/operativ2019/ibd/kindj/infin2019_u.htm (accessed 20 July 2020).

15. Where to invest in Ukraine in 2020? Available at: https://new.minfin.com.ua/ua/kuda-investirovat-2020 (accessed 20 July 2020). 
Maryna Anna, Volkova Ulia

Donetsk National Technical University

\section{HOUSEHOLD FINANCES IN THE STRUCTURE OF INVESTMENT RESOURCES OF THE COUNTRY}

Investment resources, of course, play a crucial role in ensuring the sustainable development of domestic enterprises. The inherent ability of investment to revitalize production processes and form the basis for sustainable development leads to interest in them from both scientists and practitioners. Moreover, when studying the sources of origin of investment resources, the greatest attention is paid to institutional investors, mechanisms and instruments for placing temporarily free financial resources available to them. However, some assets are excluded from financial turnover in the form of household savings, which can serve as an alternative source of investment resources for the country's economy.

Household finance is an important source of financial resources, given the possibility of attracting them to invest in the real sector of the economy, in particular industry. The structure of the country's economy indicates the predominant role of industry in creating domestic gross product, while industrial enterprises have a significant lack of financial resources to ensure the stable and sustainable development of their economic activities, and financial security. This encourages industries to seek alternative sources of financing. In turn, savings, which are part of household finance, and do not find application in the financial market as credit capital, can well be used as investment resources of industrial enterprises.

Household finances are a significant part of the country's financial resources, participating in the country's numerous financial flows. Today, most research on household financial resources is limited to assessing and forecasting their level and dynamics, structure, and so on. However, household finances can be used as an internal source of investment resources for domestic enterprises both through the banking system and by attracting funds directly from the population through financial instruments. Unfortunately, in Ukraine the investment potential of the household is not fully used. Households actively use informal foreign exchange savings to finance their needs, and could direct to the development of certain areas of the economic system. According to experts, today the most attractive forms of investment for the population are real estate, financial companies, and the purchase of precious metals and shares of large corporations. At the same time, further research is needed on the forms, methods and mechanisms of intensification of investment activity of domestic households in the conditions of economic and political uncertainty.

Key words: household finance, household expenditure, investment, household income and expenditure structure, savings, investment resources.

JEL classification: D14, D91, D92, G11 